\title{
Topographical Distribution of Carcinoma Larynx
}

\author{
Md. Shahjad Selim ${ }^{1}$, Md. Mozharul Islam², Md. Manjur Rahim¹, Md. Hasan Zafar ${ }^{3}$, Md. Khalid Asad $^{4}$, \\ Md. Mizanur Rahman ${ }^{5}$
}

\begin{abstract}
The larynx is the most common site for primary tumour of the head and neck region. It represents world wide approximately $1-2 \%$ of all cancers. A cross sectional study of 154 cases of laryngeal carcinoma was carried out in the in-patient department of Bangabandhu Sheikh Mujib Medical University and Dhaka Medical College during the period of two years with an aim to find out the frequency of site and subsite involvement of carcinoma of the larynx. The age range is 33-80 years and the over all male to female ratio is 29.8:1. Smoking and chewing habit are the most important associated factors. Majority of growths are found to be exophytic and most of the patients present at advanced stage. The commonest site of laryngeal carcinoma is supraglottic region and occurrence of supraglottic carcinoma than glottic carcinoma is statistically highly significant.
\end{abstract}

Keywords: Carcinoma, larynx, supraglottic, glottic

1. Assistant Professor, Dept. of ENT. Kushtia Medical College. Kushtia.

2. Assistant Professor, Dept. of ENT. Kushtia Medical College. Kushtia.

3. Assistant Professor, Dept of ENT. Cox's Bazar Medical College, Cox's Bazar.

4. Assistant Professor, Dept. of ENT. Shaheed Syed Nazrul Islam Medical College, Kishorganj.

5. Senior Consultant, Dept. of ENT. 250 Bedded District Hospital, Magura.

Address of correspondence: Dr.Md. Shahjad Selim, Assistant Professor, Dept. of ENT. Kushtia Medical College. Kushtia. E-mail: shahjadselim@gmail.com

\section{Introduction}

Carcinoma of the larynx is not an uncommon disease. The larynx is the most common site for primary malignant tumour in head and neck region. ${ }^{1,2,3,4}$ It represents world wide approximately $1-2 \%$ of all cancers. ${ }^{5}$ It has been estimated that in Britain, there are about 5000 new cases of head and neck cancer each year, excluding superficial skin cancer. ${ }^{6} \quad 30-40 \%$ of these are laryngeal cancer. ${ }^{7}$ The American cancer society estimated approximately 12000 new cases of laryngeal cancer in USA in $1996 .{ }^{\circ}$

A higher incidence of laryngeal cancer has been reported from Asian population. In a study in
Dhaka Medical College Hospital, it was seen that $35.32 \%$ of all body cancers in head and neck region and carcinoma of larynx was the commonest in head and neck region (31.58\%). ${ }^{3}$ Laryngeal cancer was one of only a few type of cancer with high rate of cure which, in certain subsite, may reach over $85 \%$ and overall exceeds $50 \% .^{9}$ Carcinoma of the larynx, therefore places upon the clinician a much greater responsibility than usual, for careful evaluation and treatment offer a possibility of cure while, in common with a number of other head and neck cancer, failure may be followed by a relatively uncomfortable death. 
Subsite distribution of carcinoma of larynx varies world wide. In this subcontinent, supraglottic carcinoma is more common. ${ }^{2,3}$ It was found $56 \%, 67 \%$ and $70 \%$ of cases in different studies. $^{10,11,12} \quad$ Incidence of supraglottic carcinoma is also higher in European countries like France, Italy. ${ }^{9}$ Where as glottic carcinoma is more prevalent in UK and North America (50\% and $60 \%$ respectively)..$^{13}$

Previous studies in our country showed that supraglottic carcinoma topped the list among all types of carcinoma of the larynx. Although numerous studies on carcinoma of the larynx have been done in different countries, a few data are available on topographical distribution in our population.

Our present study is intended to outline the distribution of laryngeal carcinoma in different anatomical regions and sites according to frequency. The result of this study will provide some knowledge that may help in the early diagnosis and choice of treatment modalities. It may also have some prognostic values. We will also try to reveal the association of causative factors like smoking, tobacco chewing and ingestion of alcohol or any other new factors and carcinoma of the larynx in this study.

\section{Objectives}

1. To find out the frequency of site of involvement of carcinoma of the larynx.

2. To identify carcinoma of larynx by direct laryngoscopy and detect primary

3. To confirm the diagnosis by histological examination.

\section{Methods}

Type of study: Cross sectional.

Place of study: Department of OtolaryngologyHead and Neck surgery of Bangabandhu Sheikh Mujib Medical University Hospital and Dhaka Medical College Hospital.

Period of study: July 2005 to June 2007 .
Study population: All cases of laryngeal carcinoma in these two hospital during the study period.

Sample size: $n=154$.

Selection of patients:

Inclusion criteria: Histologically diagnosed case of carcinoma of the larynx.

Exclusion criteria: Cases of pharyngeal tumour extending to larynx.

\section{Results}

Table I: Age distribution of patients of carcinoma of larynx $(n=154)$

\begin{tabular}{|l|c|c|}
\hline Age in years & $\begin{array}{l}\text { Number of } \\
\text { patients }\end{array}$ & Percentage \\
\hline $31-40$ & 18 & 11.69 \\
\hline $41-50$ & 30 & 19.48 \\
\hline $51-60$ & 59 & 38.31 \\
\hline $61-70$ & 41 & 26.62 \\
\hline $71-80$ & 6 & 3.89 \\
\hline Total & 154 & 100 \\
\hline
\end{tabular}

Table II: Sex distribution of patients of carcinoma of larynx $(n=154)$

\begin{tabular}{|l|c|c|}
\hline $\begin{array}{l}\text { Sex } \\
\text { patients }\end{array}$ & $\begin{array}{l}\text { Number of } \\
\text { patients }\end{array}$ & Percentage \\
\hline Male & 149 & 96.75 \\
\hline Female & 5 & 3.25 \\
\hline Total & 154 & 100 \\
\hline
\end{tabular}


Table III: Personal habits of patients of carcinoma of larynx $(n=154)$

\begin{tabular}{|l|c|c|}
\hline Type of habit & $\begin{array}{l}\text { Number of } \\
\text { patients }\end{array}$ & Percentage \\
\hline Smoking & 61 & 39.61 \\
\hline $\begin{array}{l}\text { Chewing betel } \\
\text { leaf with } \\
\text { tobacco }\end{array}$ & 16 & 10.38 \\
\hline $\begin{array}{l}\text { Smoking \& } \\
\text { chewing betel } \\
\text { leaf with } \\
\text { tobacco }\end{array}$ & 69 & 44.81 \\
\hline $\begin{array}{l}\text { Smoking, } \\
\text { tobacco } \\
\text { chewing and } \\
\text { alcohol }\end{array}$ & 3 & 1.95 \\
\hline $\begin{array}{l}\text { Smoking and } \\
\text { alcohol }\end{array}$ & 1 & 0.65 \\
\hline None & 4 & 2.60 \\
\hline Total & 154 & 100 \\
\hline
\end{tabular}

Table IV: Distribution of site of involvement of carcinoma of larynx according to International Classification of Diseases for Oncology (ICD- o) $(n=154)$

\begin{tabular}{|l|l|c|c|}
\hline $\begin{array}{l}\text { ICD-O } \\
\text { site } \\
\text { code }\end{array}$ & Site & $\begin{array}{l}\text { No of } \\
\text { patient }\end{array}$ & Percentage \\
\hline C 32.1 & Supraglottic & 119 & 77.27 \\
\hline C 32.0 & Glottic & 34 & 22.08 \\
\hline C 32.2 & Subglottic & 1 & 0.65 \\
\hline & Total & 154 & 100 \\
\hline
\end{tabular}

Table V: Distribution of nodal involvement of patients of carcinoma of larynx $(n=154)$

\begin{tabular}{|l|c|c|}
\hline $\begin{array}{l}\text { Neck node } \\
\text { status }\end{array}$ & $\begin{array}{l}\text { Number of } \\
\text { patients }\end{array}$ & Percentage \\
\hline $\begin{array}{l}\text { Node } \\
\text { involved }\end{array}$ & 72 & 46.75 \\
\hline $\begin{array}{l}\text { Node not } \\
\text { involved }\end{array}$ & 82 & 53.25 \\
\hline
\end{tabular}

Table VI: Lymph node involvement according to site of carcinoma of larynx $(n=154)$

\begin{tabular}{|l|c|c|}
\hline Site & $\begin{array}{l}\text { Number of } \\
\text { patients with } \\
\text { neck node } \\
\text { involvement }\end{array}$ & Percentage \\
\hline $\begin{array}{l}\text { Supraglottic } \\
(119)\end{array}$ & 71 & 98.61 \\
\hline Glottic (34) & 1 & 1.39 \\
\hline Total & 72 & 100 \\
\hline
\end{tabular}

Table VII: Distribution of status of involved neck node $(n=72)$

\begin{tabular}{|l|c|c|}
\hline $\begin{array}{l}\text { Status of neck } \\
\text { node }\end{array}$ & $\begin{array}{l}\text { Number of } \\
\text { patients }\end{array}$ & \\
\hline $\mathrm{N}_{1}$ & 47 & 65.28 \\
\hline $\mathrm{N}_{2}$ & 16 & 22.22 \\
\hline $\mathrm{N}_{3}$ & 9 & 12.50 \\
\hline Total & 72 & 100 \\
\hline
\end{tabular}

Table VIII: Pattern of growth of carcinoma of the larynx $(n=153)$

\begin{tabular}{|l|c|c|}
\hline Type of growth & $\begin{array}{l}\text { Number of } \\
\text { patients }\end{array}$ & Percentage \\
\hline Exophytic & 111 & 72.55 \\
\hline Ulcerative & 42 & 27.45 \\
\hline Total & 153 & 100 \\
\hline
\end{tabular}

Table IX: Comparison of extension of carcinoma of larynx: Supraglottic Vs Glottic $(n=153)$.

\begin{tabular}{|l|l|c|c|c|c|}
\hline Site & $\mathrm{T}_{1}$ & $\mathrm{~T}_{2}$ & $\mathrm{~T}_{3}$ & $\mathrm{~T}_{4}$ \\
\hline \multirow{2}{*}{ Supraglotti } & Number & 15 & 43 & 57 & 4 \\
\cline { 2 - 6 } $\mathrm{C}$ & Percentag & 12.6 & 36.1 & 47.9 & 3.3 \\
$\mathrm{~N}=119$ & $\mathrm{e}$ & 0 & 3 & 0 & 6 \\
\hline Glottic & Number & 4 & 14 & 15 & 1 \\
\cline { 2 - 6 } $\mathrm{N}=34$ & percentage & 11.7 & 41.1 & 44.1 & 2.9 \\
& & 6 & 8 & 8 & 4 \\
\hline
\end{tabular}


Table $X$ : Histological grading of carcinoma of larynx $(n=154)$

\begin{tabular}{|l|l|c|c|}
\hline $\begin{array}{l}\text { Degree of } \\
\text { differentiation }\end{array}$ & Grading & $\begin{array}{l}\text { No. of } \\
\text { patients }\end{array}$ & Percentage \\
\hline $\begin{array}{l}\text { Well } \\
\text { differentiated }\end{array}$ & Grade I & 67 & 43.50 \\
\hline $\begin{array}{l}\text { Moderately } \\
\text { differentiated }\end{array}$ & Grade II & 79 & 51.30 \\
\hline $\begin{array}{l}\text { Poorly } \\
\text { differentiated }\end{array}$ & $\begin{array}{l}\text { Grade } \\
\text { III }\end{array}$ & 8 & 5.20 \\
\hline
\end{tabular}

Table XI: Clinical staging of patients of carcinoma of larynx by TNM classification. $(n=154)$

\begin{tabular}{|l|c|c|}
\hline $\begin{array}{l}\text { Clinical } \\
\text { staging }\end{array}$ & $\begin{array}{l}\text { Number of } \\
\text { patients }\end{array}$ & Percentage \\
\hline Stage I & 16 & 10.39 \\
\hline Stage II & 33 & 21.43 \\
\hline Stage III & 76 & 49.35 \\
\hline Stage IV & 29 & 18.83 \\
\hline Total & 154 & 100 \\
\hline
\end{tabular}

\section{Discussion}

Larynx is the most common site of head and malignancies. ${ }^{1,2,3}$ The incidence of laryngeal carcinoma varies from country to country. It represent $1.3 \%$ of all malignancies in male and $0.4 \%$ of all malignant tumours in female excluding basal cell and squamous cell carcinoma of skin. ${ }^{14}$

The age of the patients ranged from 33 to 80 years, and the mean age was $55.37 \%( \pm 12.36)$ years in this study. Two previous studies in Bangladesh also found similar age distribution, ${ }^{11,12}$

Here the peak incidence of laryngeal carcinoma were at sixth (38.31\%) and seventh $(26.62 \%)$ decades respectively. Other studies also support that the peak incidence of laryngeal carcinoma is at the $6^{\text {th }}$ or $7^{\text {th }}$ decade. ${ }^{12,15,16,17}$ However the peak incidence of laryngeal carcinoma may not indicate that the risk is lower at higher age groups. Rather it is due to reducing number of person surviving as age progresses; the actual number of cases falls with age..$^{18}$ In Bangladesh the relative frequency of people above the age of 65 years is only $3 \% .^{19}$

In this study, $96.75 \%$ were male whereas female were $3.25 \%$. The overall male to female ratio was 29.8:1. Review of literature reveals that there is wide geographical variation in sex distribution of laryngeal carcinoma. The ratio was described as 2:1 in Scotland and 3:1 in UK and 9:1 in France. ${ }^{13}$ In Canada and Italy, the ratio was found to be $6: 1$ and $32: 1$ respectively. ${ }^{9}$

In this study, $87.02 \%$ of the patients had the habit of smoking. Other personal habits were chewing betel leaf $(64.28 \%)$, chewing tobacco $(57.14 \%)$ and alcohol consumption (2.6\%). It has been described in different studies that tobacco and alcohol are clearly associated with laryngeal carcinoma. ${ }^{13}$

Neck swelling as a leading symptom was present in $27.45 \%$ of patients. In most cases, the swelling was painless (due to enlarged cervical lymph node). It occurs more frequently in supraglottic carcinoma. Neck swelling as a presenting symptom was found in other studies as $13.4 \%$ and $44.16 \%$ of cases. ${ }^{8,10}$

Cervical lymphadenopathy as a sign was third commonest one in the series. $46.75 \%$ of total patients had cervical lymphadenopathy. Commonest stage of lymphadenopathy was N1 $(65.28 \%)$. Relative frequency of $\mathrm{N} 2$ and N3 stage were $22.22 \%$ and $12.50 \%$ respectively among the cases of lymphadenopathies. Lymphadenopathy was present in a much higher frequencies in supraglottic carcinoma (59.66\%) than in glottic carcinoma (12.54\%). The difference is stastically highly significant $(p<0.001)$. This is similar to distribution of lymphadenopathy in supraglottic and glottic carcinoma. $^{9}$

In this study incidence of supraglottic carcinoma was found $77.27 \%$ of cases which clearly predominant over glottic carcinoma $(22.08 \%)$. Only one case of subglottic carcinoma was found $(0.65 \%)$. The occurrence of supraglottic than glottic carcinoma is statistically highly 
significant $(p<0.001)$. It is very much similar with the studies done in this subcontinent. In this subcontinent supraglottic carcinoma is more common. ${ }^{2,3}$ It was found $56 \%, 67 \%$ and $70 \%$ of cases in different studies. ${ }^{10,11,12}$ The incidence of supraglottic is also higher in European countries like France, Italy. ${ }^{9}$ Where as glottic carcinoma is more prevalent in UK and also in North America (50\% and $60 \%$ respectively). ${ }^{13}$ Incidence of subglottic is very insignificant world wide. Our study also consistent with this finding.

In our study, sub sites involvement of supraglottic carcinoma showed that involvement of combined location was significantly higher than other subsites $(p<0.001)$. Involvement of epiglottis (3.56\%), aryepoglottic fold (5.88), arytenoid $(2.52 \%)$, ventricular band $(0.84 \%)$ were much lower than the combined site. Involvement of the combined site is frequently higher than single subsite involvement $(P<0.001)$. This finding is consistent with the study in Bangladesh, ${ }^{1}$ but differ from western world where epiglottis is the common subsite involved in supraglottic carcinoma of larynx. ${ }^{13}$

Majority of growths were exophytic (72.55\%). Ulcerative lesions were $(27.45 \%)$. Similar observation was made by a study in Bangladesh. ${ }^{11}$

In supraglottic carcinoma larynx, tumour stages at presentation were $\mathrm{T}_{1}(12.60 \%), \mathrm{T}_{2}(36.13), \mathrm{T}_{3}$ $(47.90 \%)$ and $\mathrm{T}_{4}(3.36 \%)$. This result is consistent with study performed in our country, ${ }^{11}$ but differ from subsite in western countries. In glottic carcinoma, the result was $\mathrm{T}_{1}(11.76 \%)$, $\mathrm{T}_{2}(41.18 \%), \mathrm{T}_{3}(44.18 \%)$ and $\mathrm{T}_{4}(2.94 \%)$. This finding are also similar with the result of Amin et al (1991). ${ }^{11}$ Our result differ from the studies done abroad as our patients seek medical advice late for various factors.

Regarding staging, our study revealed that most of the patients present at stage III $(49.35 \%)$, followed by stage II $(21.43 \%)$, stage IV $(18.83 \%)$, and stage I $(10.39 \%)$. So most of the patients present at advanced stage $(68.18 \%)$.
In this study the commonest type was moderately differentiated (Grade II) carcinoma $(51.30 \%)$. Finding in this study was consistent with a previous study done in Dhaka, ${ }^{12}$ but the current study is dissimilar with another study. ${ }^{10}$

\section{References}

1. Haque S.F. Cancer incidence in Bangladesh. Journal of Bangladesh College of Physician and Surgeon, 1987; 5: 1-7.

2. Chakraborty S., Kar T. K., Ghose I. M. Neoplasm of the Ear, Nose and Throat. The Indian Journal of Otolaryngology and Head and Neck Surgery, 1992; 11318.

3. Alauddin M., Ahmed K., Chowdhury M. A., Sarker M. R. I. Head and Neck Cancer- A study of 4215 cases. Bangladesh Journal of Otorhinolaryngology, 1997; 3: 39-41.

4. Hoffman H. T., Karnell L. H., Funk G. F., Robinson R. A., Menk H.R. The National Cancer Database Reports of Cancer of the Head and Neck. Archives of Otolaryngology and Head and Neck Surgery, 1998; 124: 951-62.

5. Makitie A., Pukender J., Raitiola H., Hyrynkangas K., Koivanen P., Virtabiemi J., Grenman J. Changing trend in the occurrence and subsite distribution of laryngeal cancer in Finland. European Archives of Otolaryngology, 1999; 256:277-9.

6. Tobias J. S. Management of Head and Neck Cancer in Britain. British Medical Journal, 1997; 315: 1556-9.

7. Gibson A. R., McCombe A. W. Physiological Morbidity Following Laryngectomy: A Pilot Study. The Journal of Laryngology and Otology, 1999; 113: 349-52. 
8. Shah J. P., Karnell L. H., Hoffman H. T., Arian S., Brown S., Fee W. E., Glass A.G., Goepfert H., Ossoff R. H., Fregman A. Pattern of Care for Cancer of the Larynx in the United States. Archives of Otolaryngology and Head and Neck Surgery, 1997; 1236: 476-83.

9. Robin P. E., Olofsson J. Tumour of the Larynx. In: J. Hibbert ed. Laryngology and Head and Neck Surgery, ScottBrowns Otolaryngology: $6^{\text {th }}$ edition. Oxford: Butterworth-Heinemann. 1997; 11/1-43.

10. Verma A., Metha S., Panda N. K., Mann S. B. S., Mehra Y. N. Presentation of Carcinoma of Larynx and Laryngopharynx- An analysis of 840 cases. Indian Journal of Otolaryngology, 1990; 42: 50-53.

11. Amin M.N., Datta P.G., Amin A.S.A.,Kadir A. Clinical Presentation of Carcinoma of Larynx. Journal of Bangladesh College of Physician and Surgeon, 1991; 8: 10-16.

12. Akhter PS, Sharma SK, Chowdhury T. Laryngeal Tumour and Radiation Response-A study of 100 cases. Journal of Bangladesh College of Physician and Surgeon, 1993; 11: 82-88.

13. Watkinson J.C., Gaze M,N., Wilson J.A. Tumours of the Larynx. Stell and Maran's Head and Neck Surgery. $4^{\text {th }}$ ed. Oxford: Butterworth-Heinemann. 2000,197-214.

14. Thawley S. E. Cysts and Tumours of the Larynx. In: W. Karnell ed. Otolaryngology. $3^{\text {rd }}$ edition. Philadelphia: W B Saunders Company. 1991. 230767.

15. Sharma M., Changani D. L. Malignancy of Larynx and Hypopharynx. Indian Journal of Otolaryngology and Head Neck Surgery, 1992; 1: 93-5.
16. Alauddin M. Surgical salvage in Cancer of the Larynx. Journal of Bangladesh College of Physician and Surgeon, 1992; 10: 69-73.

17. Adams G. L., Maisel R. H. Malignant tumours of Larynx and Hypopharynx. In: W Brothers ed. Otolaryngology and Head Neck Surgery. $3^{\text {rd }}$ edition. St. Louis Missouri: Mosby Year book, 1998. 2130-75.

18. Ramadan H., Pukander J. Symptoms of Laryngeal Carcinoma and Their Prognostic Significance. Acta Otolaryngology, 2000; 39: 213-6.

19. ESCAP Population Data Sheet. The Population of Rural and Urban Development Division. Economic and Social Commission for Asia and the Pacific, United Nation Building, Bangkok. 2000. 